\title{
HUBUNGAN SOSIAL MASYARAKAT MULTIETNIK DI KABUPATEN LUWU SULAWESI SELATAN
}

\author{
The Social Relationship of Multiethnic Society in \\ North Luwu Regency South Sulawesi
}

\author{
Abdul Hafid \\ Balai Pelestarian Nilai Budaya Makassar \\ Jl. Sultan Alauddin-Tala Salapang Km 7, Makassar 90211 \\ Email: hafidabdul30@yahoo.com
}

Naskah diterima tanggal 29 September 2016. Naskah direvisi tanggal 20 Oktober 2016. Naskah disetujui tanggal 9 November 2016.

\begin{abstract}
Abstrak
Masyarakat Sukamaju, Kabupaten Luwu Utara merupakan masyarakat multietnik. Pada umumnya, mereka merupakan transmigrasi dari Jawa, Bali dan lombok. Sebagian juga, mereka berasal dari warga masyarakat Sulawesi Selatan, yaitu Toraja dan Bugis. Dalam hubungan sosial sehari-hari, baik antarsesama etnik maupun antaretnik terjalin hubungan harmonis, rukun dan damai. Perbedaan budaya dan agama bukan menjadi hambatan dan pemisah dalam hubungan sosial, tetapi menjadi daya pemikat untuk saling menghargai dan menghormati. Kondisi seperti itu menciptakan hubungan sosial yang terintegrasi dalam kelompok masyarakat yang heterogen. Tulisan ini merupakan hasil penelitian, yang bertujuan untuk mengungkapkan dan menjelaskan tentang hubungan sosial masyarakat multietnik di pemukiman transmigrasi Sukamaju, dalam intraksi yang bersifat assosiatif dan disasosiatif. Metode penelitian yang digunakan adalah kualitatif deskriftif, dengan teknik wawancara, pengamatan dan studi pustaka dalam pengumpulan data. Hasil penelitian menunjukkan bahwa hubungan sosial yang bersifat asosiatif terjalin dengan cara memperkuat solidaritas dan gotong-royong antar etnik. Walaupun ada perbedaan budaya dan agama yang mewarnai kehidupan sosial masyarakat, tetapi, masyarakat mampu menjalin hubungan sosial dengan baik melalui proses kerjasama, akomodasi, asimilasi dan akulturasi. Hubungan sosial yang bersifat disasosiatif dikelolah dengan meminimalisir kemungkinan akan terjadinya konflik dari proses hubungan persaingan dan kontroversi.
\end{abstract}

Kata Kunci: relasi sosial, multietnik, masyarakat Sukamaju, Luwu Utara.

\begin{abstract}
Sukamaju society in North Luwu are multi-ethnic. In general, they are transmigration from Java, Bali and Lombok. Some of them are also from South Sulawesi, namely Toraja and Bugis. The social relations that happen everyday, both ethnic and inter-ethnic have established a harmonious, friendly and peace relationship. Differences in culture and religion are not a barrier and separator in social relationships, but being a lure for mutual appreciate and respect. Such conditions create social relationships that are integrated in heterogeneous groups. This is the result of research, which aims to reveal and explain the social relations of multi-ethnic society in Sukamaju transmigration settlement through associative and disassociative interactions. The method used is descriptive qualitative by interview, observation, and literature in collecting data. The results showed that the associative social relations are formed by strengthening solidarity and helping each of inter-ethnic. Although, there are cultural and religious differences that characterize the social life of community, however, the public is able to establish social relationships well through the process of cooperation, accommodation, assimilation and acculturation. Disassociative social relation is managed by minimizing the possibility of conflict in the competition and controversy.
\end{abstract}

Keywords: social relations, multiethnic, Sukamaju society, North Luwu. 


\section{PENDAHULUAN}

$\mathrm{M}$ anusia merupakan mahluk sosial yang tidak dapat hidup sendiri oleh karena itu manusia hidup dalam suatu kelompok yang disebut dengan masyarakat. Masyarakat adalah sekumpulan manusia yang saling bergaul atau dengan istilah ilmiah, saling berinteraksi (Koentjaraningrat, 2009: 144). Interaksi sosial dapat diartikan sebagai hubungan-hubungan sosial yang dinamis. Hubungan sosial yang dimaksud dapat berupa hubungan antara individu yang satu dengan individu lainnya, antara kelompok yang satu dengan kelompok lainnya, maupun antara kelompok dengan individu.

Hubungan antara satu kelompok dengan kelompok lain merupakan wujud interaksi sosial yang didorong oleh adanya saling ketergantungan kebutuhan antara sesama manusia. Interaksi sebagai bentuk hubungan antar manusia tidak dapat dilepaskan dari berbagai aspek yang mengitari kehidupan manusia itu sendiri. Interaksi dapat terjadi karena pertemuan langsung antar individu dan dapat pula terjadi karena persentuhan antar ide, paham dan budaya. Interaksi sosial dapat terjadi jika terdapat kontak sosial dan komunikasi, yang dapat dilihat dari dasar sudut pandang psikologis dan sosiologis.

Hal ini akan bermuara pada persepsi dan sikap terhadap kelompok di luar kelompoknya yang diawali dengan pengklasifikasian orang ke dalam pengertian tertentu. Kontak sosial merupakan produk dari persentuhan antar pribadi yang akan membentuk kelompok-kelompok sesuai dengan persamaan-persamaan yang mereka miliki, seperti persamaan bahasa, persamaan budaya, agama dan lain sebagainya. Individu-individu di suatu wilayah akan mencari sendiri kelompok di mana mereka harus masuk dan bergabung.

Demikian halnya dalam kelompok masyarakat multikultural yang terdiri dari berbagai suku dan budaya dan etnis yang tersebar di seluruh bumi nusantara ini. Secara sosiologis, masyarakat multikultural adalah masyarakat yang memiliki keanekaragaman budaya, keanekaragaman itu biasa berkenan dengan suku, agama, ras, golongan, atau gender. Multikultural berakar pada paham multikulturalisme, yang menghendaki adanya perlakuan yang sama terhadap berbagai komunitas beragam budaya.

Multietnis atau biasa diartikan multikultural berasal dari dua kata, multi (banyak/beragam) dan kultural (budaya atau kebudayaan), yang secara etimologi berarti keberagaman budaya. Menurut Suparlan (2002:34) akar kata dari multikulturalisme adalah kebudayaan, yaitu kebudayaan yang dilihat dari fungsinya sebagai pedoman bagi kehidupan manusia. Dalam konteks pembangunan bangsa, istilah multikultural ini telah membentuk suatu ideologi yang disebut multikulturalisme. Konsep multikulturalisme tidaklah dapat disamakan dengan konsep keanekaragaman secara suku bangsa atau kebudayaan suku bangsa yang menjadi ciri masyarakat majemuk, karena multikulturalisme menekankan keanekaragaman kebudayaan dalam kesederajatan.

Para ahli ilmu sosial tersebut, pada umumnya memahami kelompok etnik sebagai sekelompok penduduk yang mempunyai kesamaan sifat-sifat kebudayaan: misalnya bahasa, adat istiadat, perilaku budaya, karakteristik budaya dan sejarah. Suku bangsa adalah golongan sosial yang dibedakan dari golongan-golongan sosial lainya oleh karena mempunyai ciri-ciri yang paling mendasar dan umum berkaitan dengan asal usul dan tempat asal serta kebudayaan. Suatu kebudayaan yang hidup dalam masyarakat dapat berwujud beranekaragam dan memiliki ciri khas masing-masing dari suatu kelompok atau daerah. Keanekaragaman suku bangsa dan budaya merupakan suatu kekayaan kebudayaan yang menjadi modal dan pilar dalam membentuk suatu negara yang kuat dan utuh. Sebaliknya keanekaragaman suku bangsa yang tidak diiringi dengan saling kerjasama dan saling menghargai antar suku bangsa yang satu dengan suku bangsa yang lain akan menjadi potensi konflik dan pada akhirnya akan menimbulkan disintegrasi bangsa (Arios dalam Iriani 2003:1).

Oleh karena itu, penelitian tentang hubungan sosial di pemukiman transmigrasi perlu dilakukan, seperti halnya di daerah transmigrasi Sukamaju yang penduduknya terdiri atas berbagai etnis dan latar belakang budaya yang berbeda. Masing-masing etnis tersebut memiliki strategi dalam hubungan sosial dengan etnis yang berbeda guna menjalin hubungan yang harmonis. Keanaekaragaman budaya, etnis dan agama di daerah transmigrasi Sukamaju sangat memungkinkan terjadi benturan budaya, konflik antar agama atau pertikaian antar kelompok dan individu. Namun kenyataan tersebut tidaklah demikian, masyarakat transmigrasi di Sukamaju sampai saat ini tetap hidup dalam kedamaian. Hubungan sosial berjalan secara harmonis, interaksi antar individu dan kelompok 
selaras dalam suasana kebersamaan, toleransi yang tinggi antar pemeluk agama. Kenyataan inilah yang menggugah kami untuk melakukan penelitian, untuk mengetahui bagaimana sebenarnya hubungan sosial yang terbina selama ini antar kelompok etnis yang memiliki keberagaman budaya. Fokus masalah dalam penelitian ini adalah bagaimana proses hubungan sosial masyarakat multietnik di pemukiman transmigrasi Sukamaju?.

Penelitian ini bertujuan mengetahui proses hubungan sosial masyarakat multietnik di pemukiman transmigrasi Sukamaju. Tulisan ini, diharapkan dapat memberikan informasi atau masukan kepada berbagai kalangan yang berkepentingan yang berkenaan dengan hubungan sosial dengan etnis yang berbeda, dalam rangka menjalin hubungan yang harmonis pada pada masyarakat hetoregen pada umumnya dan masyarakat transmigrasi Sukamaju pada khususnya. Selain itu, diharapkan pula dapat menjadi masukan bagi pengambil kebijakan dalam rangka pembinaan dan pengembangan masyarakat multietnik, khususnya dalam pembentukan jati diri dan pembangunan karakter bangsa.

\section{Tinjauan Pustaka}

Sebagai perbandingan berkenaan konten artikel ini, maka ada beberapa hasil penelitian yang mengungkapkan hubungan sosial masyarakat multietnik seperti yang dikemukakan oleh Bumulo (2013: 10) yang melakukan penelitian tentang keserasian sosial hubungan antaretnik pada masyarakat multietnik di Desa Banurejo Kabupaten Pohuwato. Masyarakat Banuroja merupakan salah satu dari sederetan realitas masyarakat heterogen, yang sering diterpa gelombang disintegrasi sosial, namun setiap terpaan tersebut mampu mereka bendung, sehingga kehidupan sosial masyarakat sampai saat iniberlangsung dengan damai. Demikian halnya dengan penelitian yang dilakukan Eka Henry dkk (2013: 7) menemukan bahwa, pasca konflik di daerah Sambas tahun 1999 dengan pengusiran suku Madura, kini suku-suku di Sei Kelambu tersebut dapat hidup berdampingan dengan damai dan saling bekerjasama dengan baik. Tidak ditemukan adanya segresi di dalam masyarakat berdasarkan perbedaan suku. Kerjasama dilakukan oleh anggota masyarakat dalam kegiatan gotong royong, keagamaan hingga kegiatan yang berkenaan dengan pelaksanaan adat istiadat.

Berkaitan dengan intraksi sosial pada masyarakat multietnik pada penelitian Huda dan Wibowo (2013: 25) tentang Interaksi Sosial Suku Samin Dengan Masyarakat Sekitar di Desa Margomulyo, bentuk interaksi yang terjadi antara suku Samin dengan masyarakat sekitarnya berupa asosiatif maupun bentuk disosiatif. Bentuk asosiatif ini bersifat positif berupa kerja sama dalam hal gotong royong, terdapat akomodasi yang dapat menetralisir melalui musyawarah dan membuat perjanjian untuk kepentingan bersama.

Kondisi yang sama terjadi pula pada masyarakat multietnik di pemukiman transmigrasi Kecamatan Sukamaju yang merupakan pemekaran dari Kecamatan Bone-Bone Kabupaten Luwu Utara. Transmigran yang ada di Sukamaju berasal dari berbagai etnis, yaitu Jawa, Bali, dan Lombok, Bugis dan Toraja. Hal ini menyebabkan keanekaragaman etnis dan budaya di daerah pemukiman transmigrasi di Sukamaju. Keanekaragaman etnis dan budaya tersebut akan mempengaruhi hubungan sosial dalam kelompok masyarakat di manapun berada, termasuk di pemukiman transmigrasi.

Menurut Raharjo dalam Gustina (2002:1) kontak atau pertemuan dua etnis atau lebih di daerah pemukiman transmigrasi akan menimbulkan dua kemungkinan, yaitu yang bersifat positif dan yang bersifat negatif sebagai perwujudan dari proses interaksi. Akan menimbulkan positif apabila mereka mampu menciptakan suasana hubungan sosial yang harmonis di daerah tujuan mereka. Kemudian sebaliknya akan muncul hal yang bersifat negatif apabila masing-masing etnis tidak mampu memahami budaya etnis lain yang ada di sekitar mereka, sehingga menimbulkan banyak potensi konflik.

\section{METODE PENELITIAN}

Penelitian ini bersifat deskriptif kualitatif yang menggambarkan hubungan sosial masyarakat multietnik di pemukiman transmigrasi Sukamaju. Data yang diperoleh dari hasil wawancacara, observasi dan dokumentasi diklasifikasikan sesuai dengan gejala-gejala sosial yang dipermasalahkan, selanjutnya diformulasikan dalam bentuk narasi. Penelitian yang dilakukan menggunakan pendekatan kualitatif untuk memahami hubungan sosial masyarakat Sukamaju yang menjadi sasaran penelitian. Peneliti berusaha mengungkapkan hubungan sosial masyarakat Sukamaju yang multietnik, dengan pendekatan kualitatif dan akan dikemukakan temuan-temuan empiris yang ada 
dalam hubungan sosial di antara berbagai etnik dalam wilayah pemukiman masyarakat transmigrasi di Sukamaju.

Penelitian ini telah dilakukan di pemukiman transmigrasi Sukamaju Kecamatan Sukamaju Kabupaten Luwu Utara Provinsi Sulawesi Selatan, pada bulan Juni 2014. Penentuan lokasi penelitian dilakukan secara sengaja (purposive) dengan pertimbangan bahwa masyarakat yang bermukim di Sukamaju adalah masyarakat multietnik, yang berasal dari suku Jawa, Bali, Lombok, Toraja dan Bugis.

\section{PEMBAHASAN}

\section{Pemukiman Transmigrasi Sukamaju}

Pemukiman transmigrasi Sukamaju berlokasi di Kecamatan Sukamaju, berjarak sekitar $21 \mathrm{~km}$ dari kota Masamba Ibukota Kabupaten Luwu Utara. Jarak Kabupaten Luwu dari kota Makassar ibukota Provinsi Sulawesi Selatan sekitar $474 \mathrm{~km}$. Kondisi jalan menuju ke Kecamatan Sukamaju cukup baik beraspal mulus, karena merupakan jalan poros yang menghubungkan Kabupaten Luwu Utara dengan Kabupaten Luwu Timur. Kondisi jalan di pemukiman transmigrasi sudah beraspal terutama jalan poros yang menghubungkan desa-desa dalam wilayah kecamatan Sukamaju. Sebagian sudah ada jalan desa yang beraspal, namun sebagian masih ada jalan desa yang hanya menggunakan pengerasan, sehingga kalau musim hujan jalan tersebut menjadi becek karena genangan air hujan.

Nama Sukamaju merupakan nama yang diberikan oleh para transmigrasi yang awal mulanya bermukim di daerah yang mereka tempati sekarang ini. Maksud dari nama Sukamaju sendiri merupakan nama yang mengandung arti bahwa kampung mereka bisa memberikan keberkahan. Mereka dalam berusaha bisa berhasil dan akan terus berkembang. Pada awalnya Sukamaju adalah desa yang terbentuk pada tahun 1981, namun seiring dengan perluasan pemukiman dan kepadatan penduduk, maka pada tahun 1984 berubah menjadi kecamatan sampai dengan sekarang ini. Pada umumnya nama-nama desa yang berada dalam wilayah Kecamatan Sukamaju berasal dari nama-nama desa/kampung yang ada Pulau Jawa, karena pada awalnya, transmigran yang datang di Sukamaju sebagian besar berasal dari Pulau Jawa sekitar tahun 1973. Misalnya Desa Rawamangun, yang merupakan nama salah satu desa di Kecamatan Sukamaju, Rawamangun yang mengandung arti "rawa dibangun, karena pada mulanya wilayah pedesaan itu adalah rawa-rawa, kemudian penduduk transmigrasi, yang membentuk areal tersebut menjadi daerah pemukiman yang dalam perkembangannya menjadi desa. Adapun batasbatas wilayah di Kecamatan Sukamaju, yaitu: Sebelah Utara berbatasan dengan Kecamatan Mangkutana, Sebelah Timur berbatasan dengan Kecamatan Bone-Bone, Sebelah Selatan berbatasan dengan Kecamatan Malangke, dan Sebelah Barat berbatasan dengan Kecamatan Mappadeceng.

Kecamatan Sukamaju terdiri dari 25 desa yang semuanya berstatus definitif. Luas wilayahnya $\pm 255,48 \mathrm{~km}^{2}$. Desa yang paling jauh dari ibukota kecamatan adalah Desa Minanga Tallu, yaitu berjarak sekitar $15 \mathrm{~km}$ dari Desa Sukamaju yang juga merupakan ibukota Kecamatan Sukamaju. Desa yang memiliki luas wilayah yang terluas adalah Desa Tamboke, yaitu 63,11 km2. Jumlah penduduk di Kecamatan Sukamaju pada akhir tahun 2013 berjumlah 50.529 jiwa, dengan perbedaan jumlah laki-laki lebih banyak dibandingkan dengan jumlah perempuan. Laki-laki berjumlah 25.661 jiwa atau $50 \%$, sedangkan perempuan berjumlah 24.868 jiwa atau $49,2 \%$. Adapun mata pencaharian penduduk di Kecamatan Sukamaju sebagian besar adalah di bidang pertanian, khususnya pertanian tanaman pangan dan perkebunan, selebihnya, ada pula di bidang perdagangan, dan jasa, serta tukang.

Kecamatan Sukamaju memiliki masyarakat yang multikultural secara etnik, dan agama, maka beragam suku dan agama tersebar di wilayah tersebut. Hal itu menjadi ciri khas dari masyarakat di Kecamatan Sukamaju. Hampir semua agama yang diakui di Indonesia mempunyai penganut di kecamatan ini. Tidak mengherankan jika tempat ibadah di daerah ini baik berupa Mesjid, Gereja, maupun Pura, banyak terdapat di kecamatan Sukamaju. Sarana pendidikan di Kecamatan Sukamaju mulai dari tingkat TK sampai dengan SLTA telah tersedia.

Untuk sarana kesehatan di Kecamatan Sukamaju juga telah tersedia. Keberadaan sarana kesehatan yang mudah dijangkau oleh masyarakat agar dapat meningkatkan pelayanan yang lebih baik dan optimal. Sarana Puskesmas di Kecamatan Sukamaju terletak di ibukota kecamatan yaitu berada di Desa Sukamaju untuk menjangkau seluruh masyarakat desa. Sarana kesehatan penunjang lainnya berupa pustu sebanyak 6 unit, polindes 4 unit dan poskesdes 15 unit.

Dalam kehidupan sehari-hari, mereka saling menghormati satu sama lain walaupun berbeda 
keyakinan dan latar budaya, justru perbedaan tersebut menjadi ciri pemersatu di antara mereka. Seperti contoh yang terdapat pada setiap pintu depan rumah mereka, dipasang salam yang terdiri dari tiga bahasa.

Gambar 1: Ucapan salam di setiap pintu depan rumah penduduk

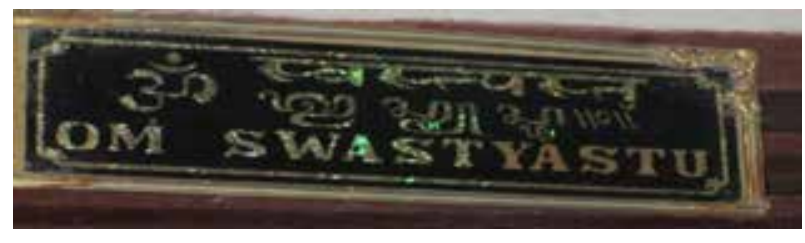

Sumber : Dokumentasi Abdul Hafid, 2014.

Sikap saling menghormati dan menghargai satu dengan yang lain terpancar dalam kehidupan para transmigran di Kecamatan Sukamaju. Tidak menjadi masalah bagi mereka untuk hidup berdampingan walaupun banyak perbedaan diantara mereka, bahkan dalam menjalani kehidupan sudah ada pembauran dan percampuran yang terjadi akibat kawin-mawin di antara mereka. Dari gambar di atas menunjukkan bahwa perbedaan bisa dipersatukan jika masing-masing orang saling menghargai satu dengan yang lain walaupun berbeda suku, agama dan ras.

Menjalin kerukunan antar umat beragama harus selalu terjalin dengan baik, apalagi berada di wilayah yang mutikultural seperti di Kecamatan Sukamaju. Oleh karena itu, setiap umat beragama diberi kebebasan dalam menjalankan ibadahnya. Peran pemerintah, tokoh-tokoh agama dan lembaga adat sangat penting untuk selalu memberikan arahan dan nasehat agar masyarakat saling hidup rukun.

Perayaan hari-hari besar keagamaan dilaksanakan sesuai dengan apa yang mereka yakini. Tidak ada larangan bagi setiap pemeluk agama dalam menjalankan hari-hari besar keagamaan mereka. Kerukunan antar umat beragama dilakukan dengan menghormati setiap perayaan keagamaan. Masyarakat yang berbeda agama turut membantu apabila ada masyarakat yang merayakan hari besar keagamaanya, demikian pula kebebasan dalam mendirikan tempat-tempat ibadah. Seperti orang Bali yang mendirikan Pura kecil di depan rumah mereka sebagai tempat sembayang dan sesaji kepada dewata. Silahturahmi dan saling kunjungmengunjungi dilakukan antar umat beragama sebagai bentuk sikap saling menghormati satu sama lain. Misalnya pada saat perayaan Hari Raya Idul
Fitri, masyarakat non datang mengunjungi saudarasaudara mereka yang sedang merayakan Hari Raya Idul Fitri, demikian pula sebaliknya dengan perayaan keagamaan yang lainnya, mereka saling kunjung-mengunjungi.

Kepercayaan masyarakat juga tidak lepas dari tradisi yang mereka bawa dari daerah asalnya. Tradisi syukuran misalnya, untuk mendapatkan hasil yang melimpah, masyarakat transmigrasi suku Jawa biasa merayakan upacara bersih desa sebagai bentuk rasa syukur. Mereka membuat sesajen yang dibacakan doa oleh Imam Desa sebagai tanda permohonan akan hasil yang melimpah dan mendoakan keselamatan desa. Kemudian, setelah didoakan, sesajen tersebut dibagi-bagikan kepada masyarakat yang berada disekitarnya dan dengan pemilik lahan yang berada dekat dengan lahan mereka.

Demikian pula kepercayaan masyarakat Bali yang menganggap bahwa hutan sebagai tempat yang suci, sebagai tempat yang memberikan kehidupan kepada mereka. Mereka percaya bahwa di hutan banyak roh-roh jahat yang bisa menggangu kehidupan mereka jika mereka merusak hutan. Kemarahan roh-roh jahat bisa mendatangkan malapetaka terhadap keluarga maupun dalam kampung mereka.

Kehidupan sosial masyarakat transmigrasi dengan penduduk lokal juga terjalin dengan baik. Pada awal kedatangan para transmigrasi ke daerah Sukamaju, penduduk lokal sering konflik dengan masyarakat pendatang mengenai lahan yang di klaim sebagai lahan dari penduduk lokal. Akan tetapi dalam perkembangannya masalah-masalah yang timbul selalu dimusyawarahkan sehingga terjalin komunikasi yang baik diantara masyarakat lokal dengan masyarakat transmigrasi. Hubungan diantara mereka sudah terjalin dengan baik, saling tolong-menolong, saling menghormati dan berbaur diantara mereka. Masyarakat meyakini bahwa rejeki yang diperoleh hanya bisa didapatkan jika mau berusaha dan bekerja keras. Oleh itu semangat dan etos kerja diantara mereka selalu menjadi dasar untuk bisa memacu diri lebih giat bekerja.

Masyarakat transmigrasi yang terdiri dari beberapa suku, seperti Jawa, Bali, Lombok, dalam perkembangannya sudah saling membaur. Tidak ada lagi pengelompokan antar suku dalam satu wilayah atau desa. Hal tersebut menjadikan masyarakat Sukamaju sudah menerima perbedaan dan menjaga perbedaan yang ada. Tidak harus merasa lebih baik dari suku yang lain, akan tetapi semua dianggap 
baik apapun suku mereka. Selain masyarakat transmigrasi, ada juga beberapa pendatang yang berasal dari beberapa wilayah di Sulawesi, seperti yang berasal dari Toraja dan Pamona. Mereka juga hidup saling berdampingan dan saling menghormati satu sama lain.

Demikian halnya dalam sistem budaya, dimana setiap masyarakat mempertahankan adatistiadat dari daerah asal mereka. Walaupun mereka berada jauh dan berada di daerah orang lain, akan tetapi mereka tetap mengingat kampung halaman mereka. Seperti dalam upacara perkawinan, dilaksanakan sesuai dengan sistem perkawinan daerah asal mereka. Jika pasangan yang akan menikah keduanya berasal dari Jawa, maka adat perkawinan yang digunakan adalah adat Jawa. Jika terjadi perkawinan campuran antara orang Jawa dengan orang Bali, maka dilihat dari garis keturunan secara patrilineal. Jika laki-laki yang akan menikah berasal dari Bali, sedangkan wanita berasal dari Jawa, maka adat perkawinan yang digunakan adalah adat Bali, demikian pula sebaliknya, jika laki-laki berasal dari Jawa, dan perempuan berasal dari Bali, maka adat perkawinan yang digunakan adalah adat Jawa. Demikian seterusnya, dimana garis keturunan dilihat dari garis keturunan ayah.

Keberagaman tradisi masyarakatnya tetap dilaksanakan sesuai dengan tradisi nenek moyang mereka. Upacara-upacara atau ritual-ritual adat tetap dilaksanakan; demikian juga dengan pengetahuan mereka dalam mengolah alam (pertanian) tetap menggunakan sistem pengetahuan lokal mereka. Pembanguan pemukiman menggunakan pengetahuan mereka mengenai corak dan ciri dari adat masyarakatnya. Sehingga pola pemukiman masyarakat di Kecamatan di Sukamaju bisa kita bedakan antara masyarakat yang berasal dari Jawa, Bali, Lombok, dan penduduk lokal dengan melihat bentuk rumah tempat tinggal mereka.

\section{Masyarakat Transmigrasi di Sukamaju}

Masyarakat Sukamaju merupakan masyarakat yang sebagian besar merupakan masyarakat pendatang dari luar pulau Sulawesi. Mereka adalah para transmigrasi yang berasal dari pulau Jawa, Bali dan Lombok. Keberadaan mereka di Sukamaju sudah berlangsung cukup lama. Kedatangan para transmigrasi ke daerah Luwu pada perkirakan awal tahun 1970-an. Namun jauh sebelumnya sekitar tahun 1934 dan 1938, sudah berdatangan penduduk suku Jawa di Bone-Bone dengan istilah kolonisasi yakni sebanyak 6.192 orang. Kemudian pada tahun 1969 terjadi transmigrasi lokal, yakni suku Pamona datang ke Bone-Bone dan menyusul suku Toraja, dan pada tahun 1975 berdatangan transmigrasi Lombok, Jawa dan Bali.

Menurut Hilda (2013:2), 'transmigrasi mulai ada di Kecamatan Bone-Bone Kabupaten Luwu sekitar tahun 1971 sampai 1973. Mereka berdatangan ketika program transmigrasi pada masa pemerintahan Soeharto sangat gencar dilaksanakan dan selanjutnya para transmigran semakin banyak berdatangan di daerah Sukamaju, yang mana pada saat itu, Sukamaju masih termasuk dalam wilayah Kecamatan Bone-Bone, Kabupaten Luwu. Asal mula transmigrasi di Kecamatan Sukamaju, di mulai pada tahun 1971, di mana para transmigran didatangkan dari wilayah Pulau Jawa dan Bali. Pada tahun tersebut jumlah kepala keluarga yang didatangkan sebanyak $200 \mathrm{kk}$, yang terdiri dari Pulau Jawa sebanyak $100 \mathrm{kk}$ (50 kk dari Jawa Timur dan $50 \mathrm{kk}$ dari Jawa Tengah), Yogyakarta sebanyak 50 kk dan Bali sebanyak $50 \mathrm{kk}$. Dengan menempuh perjalanan laut selama 5 hari, mereka tiba di Sukamaju tanggal 24 April 1971".

Kepadatan penduduk Indonesia pada masa itu terkonsentrasi di pulau Jawa dan Pulau Bali. Sedangkan wilayah yang jarang penduduknya yaitu wilayah Kalimantan, Sumatera dan Sulawesi. Oleh sebab itu pemerintah mencanangkan program transmigrasi untuk mengatasi ketidakmerataan penduduk. Transmigrasi adalah perpindahan penduduk dari wilayah yang padat penduduknya ke wilayah yang jarang penduduknya. Wilayah yang jarang penduduknya memiliki potensi lahan yang sangat luas. Pemerintah mengalokasikan orangorang dari wilayah yang padat untuk dapat hidup dan menetap di wilayah baru dengan memberikan konpensasi berupa rumah dan lahan untuk di garap masing-masing 2 hektar untuk setiap kepala keluarga. 1/4 hektar untuk rumah beserta pekarangannya, 3/4 hektar untuk mengolah tanaman perkebunan, dan 1 hektar lahan digunakan untuk area persawahan.

Asal mula transmigrasi di Kecamatan Sukamaju, di mulai pada tahun 1971, di mana para transmigran didatangkan dari wilayah Pulau Jawa dan Bali. Pada tahun tersebut jumlah kepala keluarga yang didatangkan sebanyak $200 \mathrm{kk}$, yang terdiri dari Pulau Jawa sebanyak 100 kk (50 kk dari Jawa Timur dan $50 \mathrm{kk}$ dari Jawa Tengah), Yogyakarta sebanyak $50 \mathrm{kk}$ dan Bali sebanyak $50 \mathrm{kk}$. Dengan menempuh perjalanan laut selama 5 hari, mereka 
tiba di Sukamaju tanggal 24 April 1971. Keluarga mereka inilah yang pertama kali mengolah lahan di daerah Luwu. Jauh Sebelumnya, pada tahun 1936 terjadi perpindahan penduduk ke tanah Luwu, akan tetapi mereka berada di wilayah Bone-bone dan Katulungan. Istilah perpindahan penduduk pada waktu itu dikenal dengan istilah kolonisasi. Mereka didatangkan dari Pulau Jawa dan Bali pada masa penjajahan Belanda dan merupakan proyek dari Belanda, merupakan transmigrasi pertama di daerah Luwu. Oleh sebab itu, setiap tanggal 24 April, setiap tahunnya dirayakan oleh warga Sukamaju sebagai hari jadi Sukamaju. Masyarakat multietnik Sukamaju memperingati sejarah awal mereka berada di daerah Sukamaju dan mengenang suka-duka mereka merintis sebuah lahan berupa hutan rimba, menjadi sebuah desa yang maju seperti sekarang ini.

Salah satu daya tarik masyarakat luar untuk bertransmigrasi ke Sulawesi yaitu karena adanya kabar-kabar yang mereka dengar dari media massa dan radio kalau para transmigrasi sebelumnya yang berada di Sulawesi telah cukup berhasil. Hal tersebut membuat masyarakat yang sebelumnya tidak tertarik untuk bertransmigrasi, kemudian mendaftarkan diri untuk bertransmigrasi ke Sulawesi. Mereka menentukan pilihan mereka untuk datang ke Sulawesi karena dianggap bisa mengubah nasib mereka dengan bantuan tanah luas untuk dikelola.

Kedatangan para transmigrasi ke daerah Sukamaju tahun 1971, masih membutuhkan perjuangan yang panjang. Janji pemerintah terhadap rumah, tanah yang akan di garap masih berupa hutan rimba. Rumah yang diberikan seadanya dengan luas petak $4 \times 8$ meter terbuat dari kayu, merupakan jatah per kepala keluarga. Untuk mengolah lahan, mereka harus membabat hutan yang masih lebat. Tantangan yang sangat sulit dalam pembabatan hutan adalah banyaknya binatang-binatang liar yang sewaktuwaktu membahayakan mereka. Binatang-binatang tersebut seperti ular, kera, babi hutan. Akan tetapi Pulau Sulawesi hutannya masih dianggap bersahabat jika dibandingkan Pulau Sumatera, dan Kalimantan. Ketakutan mereka di pulau lainnya yaitu, adanya binatang buas seperti Harimau.

Untuk membantu masyarakat transmigrasi di dalam mengolah lahan yang diberikan, pemerintah memberikan secara gratis peralatan pertanian seperti catut, gergaji, pacul, kampak, yang berguna untuk membabat hutan dan mengolah lahan. Sedangkan untuk memenuhi kebutuhan sehari- hari, Departemen Transmigrasi menyediakan satu tungku dan satu panci per kepala keluarga beserta dengan jatah bahan pangan. Tiap keluarga setiap bulannya menerima $15 \mathrm{~kg}$ beras, $8 \mathrm{~kg}$ untuk ibu dan $6 \mathrm{~kg}$ untuk anak, 250 gram garam, segangganm ikan kering setiap orang, sebotol minyak kelapa (0,75 liter) serta 1 liter minyak tanah untuk setiap keluarga. Untuk mengusahakan lahan, pemerintah juga memberikan beberapa bibit tanaman (Charas, 1997).

Pemberian bantuan pangan kepada setiap keluarga hanya berlangsung selama setahun. Oleh sebab itu, mereka harus segera mengusahakan lahan untuk ditanami tanaman-tanaman yang bisa dipakai sehari-hari maupun untuk di jual. Selain peralatan untuk mengolah lahan, pemerintah juga memberikan berbagai bibit tanaman agar bisa di tanam di lahan mereka. Ada juga yang membawa bibit tanaman mereka dari kampung halaman mereka ketika mereka bertransmigrasi ke Sukamaju. Dari bibit-bibit tanaman yang diberikan tersebut, mereka bisa menanami lahan mereka.

Perjuangan para transmigran untuk bisa mendapatkan hidup yang layak memang tidak mudah. Kegigihan dan keuletan mereka, menghantarkan mereka menjadi salah satu daerah transmigrasi yang berhasil. Bahkan sudah menjadi areal percontohan bagi daerah-daerah yang lain, yang ingin bertransmigrasi.

\section{Hubungan Sosial Masyarakat Multietnik Sukamaju.}

Menurut Setiadi dan Usman (2011) Interaksi sosial adalah hubungan-hubungan sosial yang dinamis yang berkaitan dengan orang perorangan, kelompok perkelompok, maupun perorangan terhadap perkelompok ataupun sebaliknya. Interaksi sosial adalah hubungan timbal balik antara individu dengan individu, individu dengan kelompok, dan kelompok dengan kelompok. Interaksi sosial merupakan intisari kehidupan sosial, artinya kehidupan sosial tampak secara konkret dalam berbagai bentuk pergaulan seseorang dengan orang lain. Selanjutnya, interaksi sosial merupakan bentuk pelaksanaan kedudukan manusia sebagai mahluk sosial. Berbagai bentuk pergaulan sosial merupakan bukti betapa manusia membutuhkan kebersamaan dengan orang lain. Bentuk interaksi sosial dibedakan menjadi dua bentuk, yaitu asosiatif dan disassosiatif. Interaksi sosial bersifat asosiatif akan mengarah pada bentuk penyatuan terdiri atas beberapa hal yaitu: Kerja sama (cooperation), 
akomodasi, asimilasi dan akulturasi. Sedang interaksi sosial disasosiatif meliputi: persaingan/ kompetisi, kontravensi dan konflik.

\section{Hubungan Sosial Asosiatif}

Hubungan sosial adalah hubungan antar manusia yang terikat dalam suatu wadah yang disebut masyarakat. Masyarakat selalu mengalami perubahan dan perkembangan, hal ini terjadi karena para warganya mengadakan hubungan satu dengan lainya baik dalam bentuk perorangan maupun kelompok sosial. Hubungan sosial asosiatif merupakan hubungan yang bersifat positif artinya hubungan ini dapat mempererat atau memperkuat jalinan atau solidaritas kelompok. Adapun hubungan sosial asosiatif meliputi :

\section{Kerjasama (cooporation)}

Kerjasama terbentuk karena masyarakat menyadari bahwa mereka mempunyai kepentingan yang sama sehingga sepakat untuk bekerjasama dalam mencapai tujuan bersama. Menurut Setiadi dan Usman (2011: 63) kooperasi atau kerjasama merupakan perwujudan minat dan perhatian orang untuk bekerja bersama-sama dalam suatu kesepahaman, sekalipun motifnya sering dan bisa tertuju kepada kepentingan diri sendiri. Berbagai macam bentuk kerjasama baik dalam kelompok kecil misalnya keluarga maupun kelompok besar pada masyarakat. Pada masyarakat pedesaan yang masih bersifat tradisional proses sosial yang berupa kerjasama cenderung bersifat spontan.

Hubungan sosial terjalin melalui kerjasama dalam bidang ekonomi dan sosial, kerjasama berlangsung secara spontan, baik dengan para migran maupun penduduk asli Luwu, yang saat ini hidup rukun dan damai. Masyarakat Sukamaju menyadari betul bahwa mereka datang ke pemukiman transmigrasi di Luwu, meninggalkan kampung halamannya dengan tujuan yang sama yaitu mau merubah nasib dan ingin hidup layak dengan lahan pertanian dan perkebunan yang diberikan pemerintah. Sehingga mereka sadar bahwa dengan hidup rukun dan damai sesama transmigrasi dapat meningkatkan produktifitas mereka dengan memanfaatkan lahan persawahan dan kebun yang diberikan masing-masing keluarga transmigrasi, seluas 1 hektar oleh pemerintah.

Kerjasama yang diterapkan dibidang pertanian dilakukan dengan membentuk kelompok tani yang terdiri dari 25 orang yang di dalamnya tergabung beberapa etnis, yaitu Bali, Jawa, dan Lombok terkadang pula ada etnis Bugis dan Luwu, akan tetapi jumlah lebih kecil. Dalam bidang perdagangan masyarakat etnis Jawa dan sebagian kecil etnis Bali membuka usaha warung makan, dan menjual barang campuran, sehingga banyak yang bekerja sama dengan orang Bugis yang lebih dulu melakukan perdagangan. Kerjasama di bidang sosial dan kemasyarakatan terjalin melalui kegotongroyongan antaretnik, saling membantu apabila ada warga yang melakukan suatu kegiatan, baik bersih-bersih lingkungan, membangun atau memperbaiki sarana dan prasarana lingkungan dan berbagai aksi sosial lainnya. Persamaan nasib menjadikan masyarakat transmigrasi di Kecamatan Sukamaju selalu mengutamakan kepentingan bersama.

\section{Akomodasi}

Akomodasi merupakan suatu proses penyesuaian antara individu dengan individu, individu dengan kelompok, atau kelompok dengan kelompok guna mengurangi, mencegah, atau mengatasi ketegangan dan kekacauan (Soekanto, 2009: 68). Akomodasi dapat diartikan sebagai suatu keadaan, di mana terjadi keseimbangan dalam interaksi antara individu-individu atau kelompokkelompok manusia berkaitan dengan norma-norma sosial dan nilai-nilai sosial yang berlaku dalam masyarakat. Pada masyarakat multietnik akomodasi dapat tercipta apabila masing-masing etnis memahami dan menghormati adat dan tradisi etnis yang hidup dalam lingkungan tempat tinggalnya.

$$
\text { Pemukiman transmigrasi Sukamaju }
$$

hubungan sosial masyarakat multietnik terjalin harmonis, karena masing-masing etnis memahami dan mau menerima budaya etnis lain, misalnya etnis Jawa dan Bali yang merupakan penduduk pertama yang datang ke Sukamaju, mau menerima dan mengerti kehidupan masyarakat lokal dan berusaha beradaptasi dengan budaya setempat. Akomodasi juga tercipta ketika terjadi pemilihan kepala desa, mereka bersaing secara sehat, masingmasing etnis mengajukan orang-orang yang dianggap mempunyai kemampuan untuk menjadi pemimpin dan dapat mengayomi semua etnis yang ada di Sukamaju. Setiap kelompok etnis berusaha meredam konflik-konflik yang mungkin timbul dalam pemilihan tersebut, sehingga siapa pun yang terpilih akan mendapat dukungan dari semua etnis dalam lingkup masyarakat di Sukamaju

\section{Asimilasi}

Proses asimilasi menunjuk pada proses yang ditandai adanya usaha mengurai perbedaan yang 
terdapat di antara beberapa orang atau kelompok dalam masyarakat serta usaha menyamakan sikap, mental, dan tindakan demi tercapainya tujuan bersama. Asimilasi timbul bila ada kelompok masyarakat dengan latar belakang kebudayaan yang berbeda, saling bergaul secara intensif dalam jangka waktu lama, sehingga lambat laun kebudayaan asli mereka akan berubah sifat dan wujudnya membentuk kebudayaan baru sebagai kebudayaan campuran (Setiadi dan Usman Kolip, 2011:81).

Proses asimilasi pada masyarakat multietnik di Sukamaju berlangsung secara perlahan-lahan, membaur dalam kehidupan bermasyarakat, dimana masing-masing etnis memiliki adat dan tradisi yang dibawa dari daerah asalnya. Ada banyak hal yang membentuk asimilasi seperti, perilaku ekonomi, pendidikan, dan pergaulan. Ketiga hal tersebut dapat membentuk asimilasi karena dapat mengarahkan multietnis untuk melakukan interaksi secara langsung dengan masyarakat lokal. Mereka dapat saling bertukar pikiran dalam banyak hal baik menyangkut kehidupan sehari-hari, menurut sudut pandang masing-masing etnis maupun kebiasaan atau budaya mereka, sehingga dari sini akan terjadi saling memahami diantara etnis berbeda.

Masyarakat etnis Bali berusaha membaur untuk menghindari perbedaan budaya dengan etnis lainnya. Misalnya etnis Bali yang bertetangga dengan orang Jawa, maka adat kebiasaan orang Jawa secara perlahan teradopsi masuk kepada kebiasaan orang Bali, demikian pula sebaliknya. Salah satu budaya yang paling mudah berbaur adalah pola makan atau menu makanan, apabila ada dua etnis atau lebih yang hidup membaur dan berinteraksi intensif, maka kebiasaan makan mereka mudah beradaptasi. Hal ini terlihat ketika orang Bali mengadakan pesta selain menyajikan makanan tradisionalnya, ada pula masakan Jawa yang dihidangkan dan bahkan ada beberapa makanan khas etnis Bugis dan Lombok yang disediakan.

Pembauran budaya dapat juga terjadi pada bahasa daerah masing-masing etnis, interaksi dalam berkomunikasi merupakan proses asimilasi yang berlangsung secara terus menurus dan intensif. Asimilasi terjadi pada perkawinan campuran antara orang Jawa dengan orang Bali, maka dilihat dari garis keturunan secara patrilineal. Jika laki-laki yang akan menikah berasal dari Bali, sedangkan wanita berasal dari Jawa, maka adat perekawinan yang digunakan adalah adat Bali, demikian pula sebaliknya, jika laki-laki yang berasal dari Jawa dan perempuan berasal dari Bali, maka adat perkawinan yang digunakan adalah adat Jawa. Perkawinan antara orang Bugis dengan orang Jawa, maka adat istiadat yang digunakan pada umumnya mengikuti pada adat istiadat masing-masing.

Pembauran bahasa berlangsung secara spontan, orang Bali dapat mengerti dan berbicara bahasa Jawa, karena bertetangga dengan orang Jawa demikian pula sebaliknya orang Jawa memahami bahasa Bali. Ketika orang Jawa berbahasa Bali akan nampak logat Jawanya, demikian pula ketika orang Bali berbicara Jawa agak susah menghilangkan medok Balinya, sehingga dalam berkomunikasi menimbulkan budaya baru yaitu bahasa Bali medok Jawa dan Bahasa Jawa yang logat Bali. Walaupun identitas budaya dan agama pada masyarakat Bali sangat dominan melekat pada kehidupan kesehariannya, namun etnis itu dapat hidup membaur dengan masyarakat Jawa, Lombok, Sunda dan etnis lokal Bugis Luwu, dipemukiman transmigrasi Sukamaju.

Penyatuan budaya terjadi pula pada perayaan keagamaan, misalnya peringatan Maulid Nabi, dimana setiap etnis melakukan tradisi yang di bawah dari daerah asal, menjadi ciri khas budaya etnis tersebut. Menurut Kepala Desa Rawamangun perayaan Maulid Nabi yang diselenggarakan masyarakat Islam di pemukiman transmigrasi Sukamaju memperlihatkan keragamaan budaya antar etnik. Masing-masing etnik menampilkan tradisi dan adat kebiasaan daerahnya, misalnya etnik Jawa menampilkan tumpeng yang dihiasi telur, begitu pula etnik Bugis dengan bakul yang berisi makanan sokko (nasi ketan) dan telur berwarna warni, etnik Lombok yang memperlihatkan berbagai ragam kue tradisional daerahnya. Perayaan Maulid Nabi yang diselenggarakan masyarakat Sukamaju memperlihatkan hubungan sosial yang masyarakat multietnik yang harmonis.

Demikian pula pada saat lebaran, menu makanan yang dihidangkan masing masing etnik sudah mengalami perubahan, rumah tangga yang dibentuk berdasarkan perkawinan campuran antar dua etnis yang berbeda yang memperlihatkan perpaduan makanan dari kedua etnis. Asimilasi terjadi bukan hanya pada lingkup rumah tangga, akan tetapi keluarga besar masing-masing pihakakan mengalami hal yang sama, seperti yang diutarakan ibu Nurhayati (35 tahun) etnis Lombok kawin dengan Mas Imam (40 tahun) etnik Jawa, mengatakan ketika pada hari lebaran saya menyediakan dua macam masakan yaitu masakan khas Lombok dan makanan khas Madura, karena biasanya keluarga 
saya yang dari Lombok menginginkan masakan Jawa demikian pula sebaliknya keluarga suami saya dari Jawa suka masakan khas Lombok, menurut mereka agar bisa beradaptasi dengan makanan khas daerah lain (Wawancara, 13/6/2014).

Asimilasi terjadi pula dalam lingkup pendidikan, sekolah yang ada di Sukamaju mulai dari tingkat Sekolah Dasar sampai tingkat Sekolah Menengah. Interaksi antara siswa dan guru, begitu pula antara siswa dengan siswa berlangsung secara natural, tidak ada kelompok minoritas dan mayoritas, semua etnis sama membaur jadi satu dalam lingkup pendidikan. Dalam mata pelajaran agama tidak ada diskriminasi, karena selain pelajaran agama Islam, ada juga pelajaran agama Hindu yang diberikan khusus pada etnis Bali. Perlakuan yang sama dan tidak membeda-bedakan antara satu etnis dengan etnis lainnya menjadikan interaksi dalam lingkungan pendidikan di Sukamaju terjalin dengan baik yang dapat mendorong siswasiswa untuk berperilaku saling menghargai dan mengasihi sesama etnis, walaupun budaya mereka berbeda satu sama lain.

\section{Akulturasi}

Proses akulturasi dapat berjalan sangat cepat atau lambat tergantung persepsi masyarakat setempat terhadap budaya asing yang masuk. Apabila masuknya melalui proses pemaksaan, maka akulturasi memakan waktu relatif lama. Sebaliknya, apabila masuknya melalui proses damai, akulturasi tersebut akan berlangsung relatif lebih cepat (Koentjaraningrat, 2009: 209). Proses akulturasi yang terjadi pada masyarakat multietnik Sukamaju berlangsung secara damai tanpa paksaan, sehingga unsur-unsur budaya antara etnis pendatang yaitu Bali, Jawa dan Lombok, dapat terakulturasi dengan budaya pada etnis lokal Bugis dan Luwu. Demikian pula sebaliknya etnis Bugis dan Luwu telah mencampuradukkan budayanya dengan budaya atau tradisi masyarakat pendatang. Proses akulturasi dapat pula terlihat pada bahasa, kepercayaan/religi, organisasi sosial dan kemasyarakatan, serta sistem pengetahuan. Pengaruh akulturasi budaya Hindu dan Islam banyak mewarnai pelaksanaan upacara tradisional pada berbagai etnis. Begitu pula tradisi dan budaya masing-masing etnis dapat masuk dan mempengaruhi budaya dan tradisi etnis lainnya.

Pada masyarakat Sukamaju proses akulturasi bahasa pada masing-masing etnis terjadi secara perlahan-lahan, sesuai intensitas komunikasi yang terjadi. Orang Jawa yang hidup berdampingan atau bertetangga dengan orang Bali, orang Bugis, Lombok dan penduduk lokal Luwu, maka secara perlahan-lahan bahasa daerah antar etnis dapat masuk dan mempengaruhi penggunaan bahasa daerah mereka. Sehingga proses komunikasi antaretnik dapat berlangsung secara damai.

Proses akulturasi terhadap kepercayaan atau religi pada masyarakat Sukamaju terlihat pula pada pengaruh budaya Hindu dan Islam yang mewarnai berbagai upacara tradisional dan berbagai tradisi yang dilakukan pada masyarakat multietnik. Orang Jawa ketika melakukan upacara tradisional, maka berbagai unsur budaya mewarnai pelaksanaan ritualnya dimana budaya Jawa yang bersumber dengan kepercayaan animisme dan dinamisme bercampur dengan budaya Islam untuk menguatkan mereka sebagai pemeluk agama Islam. Demikian pula tradisi orang Lombok, Bugis dan Luwuk mencampurkan budaya Islam dan budaya nenek moyang mereka sebagai bagian dari kegiatan ritual.

\section{Hubungan Sosial Disasosiatif}

Proses sosial disasosiatif merupakan realitas sosial dalam keadaan disharmoni sebagai akibat adanya pertentangan antar anggota masyarakat, yang mana proses sosial tersebut dipicu oleh adanya ketidakterlibatan sosial atau social disorder (Setiadi, 2010:87). Berkaitan dengan hal tersebut, maka ada beberapa proses sosial yang bersifat disasosiatif yang terjadi pada masyarakat Sukamaju, yakni sebagai berikut:

\section{Persaingan}

Persaingan yang terjadi di Kecamatan Sukamaju, khususnya dalam bidang ekonomi tidak lagi bersifat impersonal, namun bersifat pribadi, setiap keluarga masing-masing mencari peluang bisnis yang dianggap mampu memperbaiki kehidupan ekonominya. Persaingan dibidang ekonomi merupakan bentuk proses sosial disasosiatif yang cukup menonjol di wilayah transmigrasi tersebut, khususnya di Kecamatan Sukamaju. Bahkan hampir sebagian besar penduduk di Desa Sukamaju beralih profesi dari berkebun atau bertani berubah menjadi pedagang. Hal ini sangat memungkinkan penduduknya bekerja sebagai pedagang, sebab di Sukamaju terdapat pasar yang merupakan pusat transaksi jual beli barang-barang yang beranekaragam, yakni mulai dari hasil bumi, kebutuhan sehari-hari, bahkan sampai pada jenisjenis pakaian.

Selain persaingan dalam bentuk mata pencaharian atau persaingan di bidang ekonomi, 
ada juga persaingan pada sistem teknologi, yaitu pada bentuk rumah, bahkan sampai pada rumahrumah ibadah, seperti Pura tempat ibadah orang Hindu Bali. Dapat dikatakan semua orang Bali yang berada di Sukamaju memiliki Pura di rumah masing-masing dan bentuknya sangat permanen dan begitu indah dan luas. Mereka bersaing sesama etnis Bali sendiri. Hal ini bisa juga dikatakan sebagai persaingan dalam bidang budaya, dimana orang Bali selalu berusaha menampakkan identitasnya sebagai orang Bali dengan membangun Pura yang sangat mewah, bahkan lebih mewah dari pada tempat tinggalnya sendiri.

Apabila dipahami secara mendalam bahwa persaingan dapat pula mematangkan kepribadian seseorang, dan persaingan dapat pula memperluas pandangan dan pengetahuan seseorang. Persaingan juga akan mendorong seseorang untuk bekerja keras sehingga mendapatkan kemajuan-kemajuan yang berguna. Menghadapi persaingan dari luar, akan meningkatkan solidaritas ke dalam kelompok, seperti halnya para pendatang dan penduduk asli yang masing-masing meningkatkan solidaritas kelompoknya. Demikian pula masyarakat transmigrasi Bali yang memiliki tingkat solidaritas yang sangat kuat.

\section{Konflik}

Konflik merupakan salah satu proses sosial disasosiatif, sebab proses ini berakibat timbulnya perpecahan antar elemen sosial. Akan tetapi, kembali pada sifat konflik itu sendiri, dimana positif dan negatifnya gejala konflik akan sangat tergantung pada bagaimana konflik itu dikelola atau diarahkan. Ada babarapa kasus konflik yang pernah terjadi di Kecamatan Sukamaju, yakni konflik berkaitan dengan bahasa daerah, yakni antara transmigran dengan penduduk lokal. Dimana pada saat berinterkasi antar sesama transmigran yang berasal dari daerah yang sama, seperti etnis Jawa dan Bali mereka masing-masing menggunakan bahasa daerahnya, sementara penduduk lokal tidak paham atau mengerti dengan bahasa daerah para transmigran, akhirnya terjadi ketersinggungan, yakni penduduk lokal merasa tersinggung, karena merasa dirinyalah yang dicerita, padahal tidak demikian. Namun hal tersebut terjadi ketika para transmigran baru pertama tiba di Sukamaju, akan tetapi sekarang ini kesalahpahaman itu tidak lagi terjadi, mereka sudah saling memahami.

Selain konflik akibat perbedaan bahasa atau budaya antara penduduk lokal dengan transmigran, konflik masalah tanah juga pernah terjadi di Sukamaju, yakni ketika saat pertama para transmigran membuka lahan perkebunan dan pertanian. Para penduduk lokal tetap mempertahankan pohon-pohon sagu mereka, sehingga pada saat itu pembukaan lahan dijaga oleh tentara agar tidak terjadi perkelahian atau perbuatan yang anarkis antara transmigran dengan penduduk lokal (Charas, 1997:197). Kejadian tersebut membuat para transmigran merasa ketakutan dan menunggu pejabat pemerintah untuk menyelesaikan persolan tersebut. Peristiwa ini berlangsung cukup lama, namun para transmigran tetap bertahan dan pemerintah setempat selalu berusaha menjaga perdamaian antara penduduk lokal dan transmigran. Setelah beberapa tahun kemudian hal tersebut bisa teratasi, dan antara penduduk lokal dan para transmigran akhirnya bisa hidup berdampingan.

Selain persoalan tanah, persoalan binatang ternak juga menjadi sumber konflik di pemukiman transmigrasi di Sukamaju pada saat transmigrasi baru sampai ke pemukiman transmigran. Sebab penduduk lokal pada umumnya memelihara Sapi dan Kerbau yang dibiarkan berkeliaran, sehingga merusak tanaman transmigran. Pemilik Kerbau tidak merasa bersalah, sebab mereka menganggap dirinya adalah penduduk asli dan transmigran adalah pendatang, sehingga pendatang diharapkan mengalah. Penduduk lokal merasa dirinyalah yang benar, karena mereka mengklaim tanah yang ditempati oleh transmigran adalah milik mereka yang dirampas oleh pemerintah. Oleh karena itu, maka mereka/ penduduk lokal menganggap ia boleh dan bebas saja melepas binatang ternaknya. Namun permasalahan itu tidak berlangsung lama, karena dapat diselesaikan dengan damai oleh pemerintah setempat.

Pada awalnya penduduk lokal atau setempat merasa terganggu dengan kehadiran transmigrasi yang dianggap merampas tanah mereka, bahkan dianggap merusak sendi-sendi kehidupan mereka dengan kehadiran sistem pertanian yang baru, yang di bawa oleh para transmigran. Konflik tersebut berlangsung cukup lama dan bersifat anarkis, seperti yang diungkapkan oleh Charas (1997:164), bahwa hubungan antara penduduk lokal dengan transmigran tidak berjalan sebagaimana mestinya, bahkan pernah terjadi konflik terbuka antara penduduk asli dengan transmigran Jawa, sehingga menimbulkan korban jiwa. Namun seiring dengan berjalannya waktu dan diiringi dengan pemahaman 
masyarakat setempat tentang budaya transmigrasi, pada akhirnya penduduk setempat bisa menerima kehadiran para transmigrasi, bahkan sebagian besar penduduk setempat merasa senang dengan kehadiran transmigrasi yang mampu membuat perekonomian di wilayah tersebut bisa maju.

Pola interaksi pada masyarakat Sukamaju senantiasa berada pada tatanan yang harmonis, sejak kedatangan para masyarakat transmigrasi di Sukamaju tahun 1972 sampai sekarang. Kalaupun ada konflik kecil, bukan dari permasalahan dalam pemukiman transmigrasi, biasanya dari luar. Menurut warga setempat bahwa konflik yang sering terjadi biasanya dari kalangan anak muda atau remaja, misalnya apabila ada keramaian di Sukamaju banyak orang luar yang datang, berbaurnya orang luar pada suatu pesta atau panggung hiburan mudah terjadi gesekan antar remaja, sehingga menimbulkan perkelahian namun itu sifatnya insidentil dan dapat diselesaikan secara arbitrasi yaitu kesepakatan kedua belah pihak oleh aparat keamanan dan pemerintah setempat.

\section{Kontravensi}

Kontravensi merupakan salah satu proses sosial disasosiatif yang bisa saja terjadi pada setiap masyarakat, yakni usaha untuk menghalangi atau merintangi pihak lain untuk mencapai tujuan (Narwoko, 2007: 70). Hal tersebut didasari oleh rasa tidak senang karena keberhasilan pihak lain yang dirasa merugikan, namun tidak ada maksud untuk menghancurkan pihak lain. Kontravensi juga pernah terjadi di kecamatan Sukamaju, yaitu ketika para transmigran baru sampai ke lokasi pemukiman. Pada saat mereka akan membuka lahan untuk dijadikan sebagai sawah atau kebun, dengan cara menyiangi tanaman atau pohon-pohan yang masih berupa semak belukar. Para transmigran membuka lahan secara ramai-ramai, namun para penduduk lokal merasa cemburu dan sakit hati, karena mereka menganggap tanah miliknya dirampas oleh pendatang atau para transmigran.

Ketika itu penduduk lokal melakukan kontravensi secara terang-terangan agar para transmigran tidak mengambil tanah dan membuka lahan yang diklaim oleh penduduk asli sebagai tanah miliknya. Kontravensi tersebut dilakukan secara terang-terangan dan berkelompok. Akibat dari terjadinya kontravensi tersebut, maka pemerintah setempat melakukan pengawasan terhadap jalannya proses penyiangan hutan yang dilakukan oleh tentara. Hal tersebut dilakukan untuk mencegah agar kontravensi tidak sampai pada level konflik. Kerena apabila kontravensi tidak dapat diatasi, maka akan berkembang menjadi konflik dan akan semakin sulit untuk diatasi.

Selain kontravensi yang telah diungkapkan di atas, adapula kontravensi yang juga pernah terjadi di Sukamaju. Menurut Penuturan Jannatu (56 tahun), bahwa pada awal kedatangan para transmigran sering diganggu oleh penduduk lokal, ketika itu sawah penduduk transmigran selesai dibuka dan mereka sudah mulai menanam padi dan hasil panen yang didapatkan dapat dikatakan lumayan dapat memenuhi kebutuhan keluarga transmigran sampai tiba masa panen berikutnya. Namun melihat keberhasilan tersebut, penduduk lokal tidak senang dengan hal itu, maka mereka selalu menghalanghalangi agar sawah tersebut tidak ditanami padi dan berhenti mengolah lahannya. Salah satu yang dilakukan oleh penduduk lokal adalah membiarkan binatang ternaknya memasuki dan merusak tanaman para transmigran, sampai tanaman tersebut kurang berhasil akibat gangguan binatang ternak penduduk lokal (Wawancara, 7/7/2014).

Charas (1997: 197) mengemukakan, bahwa para transmigran sempat meninggalkan sawahnya setelah beberapa kali ditanami padi, yakni sekitar tahun 1976-1977, dan mereka menunggu sampai masalah tersebut selesai. Selain kontravensi pada pembukaan lahan dan dan hasil panen pada masyarakat transmigrasi berhasil, maka kontravensi tersebut juga terjadi pada tradisi dan budaya subak, yakni sistem pembagian air secara bergilir pada persawahan yang diatur oleh ketua adat, sehingga setiap pemilik sawah akan mendapatkan air secara bergiliran. Namun masyarakat setempat, khususnya penduduk lokal tidak setuju dengan sistem subak tersebut dan mereka selalu berusaha agar sistem subak tidak diterapkan dengan alasan tidak sesuai dengan budaya mereka. Oleh karena itu, sampai saat ini sistem subak di Kecamatan Sukamaju tidak diterapkan.

\section{PENUTUP}

Penelitian menunjukkan bahwa hubungan sosial di dalam masyarakat Sukamaju menunjukkan bentuk hubungan sosial multietnis yang harmonis. Keharmonisan pola hubungan sosial multietnis itu selalu diwujudkan dalam bentuk interaksi yang bersifat asosiatif dalam bentuk kerjasama, asimilasi, akomodasi, dan akulturasi. Sebagai orang pendatang masyarakat transmigrasi Sukamaju senantiasa mengutamakan perdamaian, karena pada 
prinsipnya masyarakat Sukamaju memahami bahwa kebersamaan lebih utama, perasaan senasib, sebagai perantau untuk mencari kehidupan yang lebih layak menjadi tujuan hidup masyarakat transmigrasi sejak mereka menginjakkan kakinya di pemukiman transmigrasi Sukamaju.

Untuk menghindari hubungan yang bersifat disasosiatif yang mengarah pada pertikaian antaretnik masyarakat Sukamaju senantiasa melakukan persaingan sehat, terbuka dan jujur di bidang ekonomi, kebudayaan, dan politik. Hasil penelitian ini menunjukkan pula bahwa masyarakat di kecamatan Sukamaju saat ini sedang menuju ke arah proses terwujudnya integrasi masyarakat multietnis. Hal ini karena wilayah Kecamatan Sukamaju telah puluhan tahun dihuni oleh berbagai ragam etnik, antar mereka telah saling bergaul dan berhubungan dengan bermacam-macam motif dan tujuan, dan antar mereka telah saling menghargai, menghormati, menyesuaikan diri terhadap kebudayaan yang berbeda itu. Oleh karena itu pola interaksi sosial yang ditampilkan melalui pola hubungan yang harmonis itu perlu dipertahankan dan ditingkatkan oleh warga masyarakat di Kecamatan Sukamaju. Untuk mewujudkan upaya ini, diperlukan peran tokoh-tokoh adat, agama, dan pemerintahan setempat untuk senantiasa memberi support dan motivator dalam kehidupan bermasyarakat di Kecamatan Sukamaju.

Penelitian ini merekomendasikan, hubungan sosial masyarakat multietnis Sukamaju yang sampai saat ini berjalan harmonis dapat menjadi percontohan pada kelompok masyarakat multietnis di Indonesia. Oleh karena itu, diharapkan pemerintah Kabupaten Luwu Utara dan instansi yang terkait untuk senantiasa berperan aktif dan memberi dukungan dalam menjaga keharmonisan masyarakat multietnik Sukamaju agar terhindar dari berbagai konflik yang mungkin terjadi.

\section{UCAPAN TERIMA KASIH}

Ucapan terimah kasih disampaikan kepada kepala Pemeritahan Kecamatan Sukamaju dan kepala Desa Sukamaju, serta seluruh warga masyarakat Sukamaju yang telah memberikan kesempatan kepada penulis untuk melakukan penelitian tentang hubungan sosial multietnik di pemukiman transmigrasi Sukamaju. Ucapan terima kasih saya sampaikan pula kepada Kepala Balai Pelestarian Sulawesi Selatan yang telah menugaskan penulis melakukan penelitian ini. Ucapakan terima kasih pula kepada Muhyiddin Muslimin, H. Muh. Jannatu, Nurhayati dan para informan lainnya.

\section{DAFTAR PUSTAKA}

Bumulo, Sahrain. 2013. Keserasian Sosial Hubungan Antar Etnik Pada Masyarakat Banuroja Kabupaten Pohuwato. Fakultas Ilmu Sosial Universitas Negeri Gorontalo

Charas, Muriel. 1997. Dari Hutan Angker Hingga Tumbuhan: Dewata Transmigrasi Orang Bali di Sulawesi. Yogyakarta: Gadjah Mada University Press.

Eka, Hendry, dkk. 2013. "Integrasi Sosial dalam Masyarakat Multietik" dalam Jurnal Walisongo. Volume 21 Nomor 1, Mei 2013.

Gustina, Nelvia. 2002. "Proses Sosial Antar Kelompok Etnis di Pemukiman Transmigrasi Spontan (Kasus pada Pakon Marang Kecamatan Pesisisr Selatan Kabupaten Lampung Barat Provinsi Lampung) dalam Skripsi. Fakultas Pertanian. Institut Pertanian Bogor.

Hilda, 2013. "Transmigrasi Orang Bali di Sidomakmur 1972-1980" dalam Skripsi. Makassar: Fakultas Sastra Jurusan Ilmu Sejarah Universitas Hasanuddin.

Huda, Khoirul dan Wibowo Anjar Mukti. 2013. “Interaksi Sosial Suku Samin dengan Masyarakat Sekitar: Studi Dusun Jepan Kecamatan Margomulyo" dalam Jurnal Prodi Sejarah. Volume 3 N0.1 2013.

Iriani, 2013. Hubungan Sosial Pasca Konflik. (Kasus Kelurahan Salassa dan Desa Baebunta). Makassar: De Lamacca.

Koentjaraningrat. 2009. Pengantar Ilmu Antropologi. Jakarta: PT Rhineka Cipta.

Narwoko, J Dwi dan Bagong Suyanto. 2007. Sosiologi Teks Pengantar dan Terapan. Jakarta: Kencana Prenada Media Group.

Soekanto, Soejono. 2009. Sosiologi Suatu Pengantar. Jakarta: PT Raja Grafindo Persada.

Setiadi, Elly M dan Usman Kolip. 2011. Pengantar Sosiologi. Pemahaman Fakta dan Gejala Permasalahan Sosial: Teori, Aplikasi, dan Pemecahannya. Jakarta: Kencana.

Suparlan, Parsudi. 2002. "Menuju Masyarakat Indonesia yang Multikultural". Simposium Internasional Bali ke-3 Jurnal Antropologi Indonesia, Denpasar Bali, 16-21 Juli 2002. 